\title{
Measured Sediment Yield Rates From Semiarid Rangeland Watersheds
}

\author{
M. H. Nichols \\ Author is Research Hydraulic Engineer, US Department of Agriculture-Agricultural Research Service, \\ Southwest Watershed Research Center, 2000 E Allen Rd, Tucson, AZ 85719.
}

\begin{abstract}
Data describing long-term sediment yield rates on semiarid rangeland watersheds are relatively rare. To augment existing data and gain a better understanding of the controlling variables, sediment yields from 8 subwatersheds within the US Department of Agriculture-Agricultural Research Service Walnut Gulch Experimental Watershed in southeastern Arizona were computed from stock pond sediment accumulation measurements, water level records, and estimates of sediment transported in pond overflows. Sediment accumulation records ranging from 30 to 47 years were evaluated for subwatersheds ranging in size from 35.2 to 159.5 ha. Sediment yield ranged from 0.5 to $3.0 \mathrm{~m}^{3} \cdot \mathrm{ha}^{-1} \cdot \mathrm{y}^{-1}$, with a mean of $1.4 \mathrm{~m}^{3} \cdot \mathrm{ha}^{-1} \cdot \mathrm{y}^{-1}$ and a standard deviation of $1.0 \mathrm{~m}^{3} \cdot \mathrm{ha}^{-1} \cdot \mathrm{y}^{-1}$. As expected, runoff volume was a significant factor $(P=0.005)$ in explaining the variability in sediment yield, but regression analysis demonstrated other variables are important. For example, the ratio of watershed area to main channel length significantly described $(P=0.06)$ sediment yield, suggesting that more detailed measurements are needed to characterize channel networks to relate internal watershed sediment transport and deposition processes to sediment delivery at the outlets. To generalize sediment yield rates across rangeland regions, additional research is necessary to determine the relative influence of rainfall and runoff patterns, and watershed physiographic and geomorphic characteristics on sediment transport.
\end{abstract}

\section{Resumen}

Los datos que describen las tasas de producción de sedimentos a largo plazo de las cuencas hidrológicas de los pastizales semiáridos son relativamente raros. Para aumentar los datos existentes y tener un mejor entendimiento de las variables controladoras, la producción de sedimento de 8 subcuencas, ubicadas dentro la Cuenca Hidrológica Experimental Walnut Gulch del Servicio de Investigación Agrícola del Departamento de Agricultura de los Estados Unidos en el sudeste de Arizona, fue calculada a partir de mediciones de la acumulación de sedimentos en estanques, registros del nivel de agua y estimaciones de sedimentos transportados en los sobreflujos de los estanques. Los registros de acumulación de sedimentos de un rango de 30 a 47 años fueron evaluados para subcuencas que variaron en tamaño de 35.2 a 159.5 ha. La producción de sedimentos varió de 0.5 a $3.0 \mathrm{~m}^{3} \cdot \mathrm{ha}^{-1} \cdot$ año ${ }^{-1}$, con una media de $1.4 \mathrm{~m}^{3} \cdot \mathrm{ha}^{-1} \cdot$ año $^{-1}$ y una desviación estándar de $1.0 \mathrm{~m}^{3} \cdot \mathrm{ha}^{-1} \cdot$ año $^{-1}$. Como se esperaba, el volumen de escurrimiento fue un factor significativo $(P=0.005)$ para explicar la variabilidad en la producción de sedimentos, pero el análisis de regresión demostró que otras variables son importantes. Por ejemplo, la relación del área de la cuenca con la longitud del canal principal describió significativamente $(P=0.06)$ la producción de sedimento, sugiriendo que se necesitan mediciones más detalladas para caracterizar las redes de canales para relacionar el transporte interno de sedimentos en la cuenca y los procesos de deposición con la liberación de sedimentos a los canales. Par generalizar las tasas de producción de sedimentos a través de las regiones de pastizal, se requiere de investigación adicional para determinar la influencia relativa de los patrones de precipitación y escurrimiento y las característica fisiográficas y geomórficas de la cuenca sobre el transporte de sedimentos.

Key Words: sediment measurement, ponds, soil erosion, southeastern Arizona, watershed runoff

\section{INTRODUCTION}

Soil loss and offsite damages associated with sedimentation are recognized as problems throughout arid and semiarid regions of the world, including Australia, Africa, Asia, and the Americas (Pimentel et al. 1995; UNEP 1997). Within the watersheds that make up these regions, sediment yield values can provide an

Mention of trade names or commercial products in this article is solely for the purpose of providing specific information and does not imply recommendation or endorsement by the US Department of Agriculture.

Correspondence: Dr Mary Hennessey Nichols, US Dept of Agriculture-Agricultural Research Service, Southwest Watershed Research Center, 2000 E Allen Rd, Tucson, AZ 85719. Email: mnichols@tucson.ars.ag.gov

Manuscript received 3 April 2005; manuscript accepted 8 October 2005. integrated measure of soil erosion, sediment transport, and deposition. Estimates of sediment yield are used to address a wide range of water quality and pollution problems through a variety of engineering, natural resource conservation planning, and land management methods (Toy et al. 2002). Increasingly, within the United States, non-point-source pollution is a focus of efforts to improve water quality (Perciasepe 1997), and sediment is a major water pollutant (National Research Council 1998). Recent attention to non-point-source pollutants has underscored the need for baseline sediment yield information. Unfortunately, data describing long-term sediment yield rates on semiarid rangeland watersheds are relatively rare.

Sediment yields for individual watersheds can be measured directly through reservoir sedimentation surveys. Within the United States, sediment yield data have been collected and 
published for distinct physiographic regions as part of the national sedimentation survey program (USDA 1973). Sediment yield rates determined during that program for watersheds in Arizona and New Mexico range from 0.7 to 19 $\mathrm{t} \cdot \mathrm{ha}^{-1} \cdot \mathrm{y}^{-1}$ and exhibit great variability depending on the time between successive surveys, local precipitation and runoff patterns, and watershed characteristics. These data allow for comparison across broad regions, but measurement sites are often not proximate and are of limited use for evaluating the spatial variability of sediment yields within local regions.

Throughout the southwestern United States, stock ponds temporarily detain surface water for irrigation, livestock, flood control, and wildlife. In addition, they are a convenient downstream control point for measuring sediment accumulation and computing average annual sediment yield rates. Few sitespecific, spatially distributed sediment accumulation and yield summaries have been published for small rangeland watersheds (Dendy and Bolton 1976; Renard and Stone 1982). Sediment yield rates on the US Department of Agriculture (USDA) Agricultural Research Service Walnut Gulch Experimental Watershed (WGEW) near Tombstone, Arizona, summarized through the late 1970s (Renard and Stone 1982) ranged from 0.6 to $4.3 \mathrm{t} \cdot \mathrm{ha}^{-1} \cdot \mathrm{y}^{-1}$. These data have been updated recently, and the objectives of this research were to quantify sediment yield rates on 8 small semiarid rangeland watersheds within the WGEW for the period of record from the 1960s to the present, and to determine the controlling variables.

\section{METHODS}

\section{Watershed Description}

The $150 \mathrm{~km}^{2}$ WGEW is located in the transition zone between the Sonoran and Chihuahuan Deserts in southeastern Arizona at approximately lat $31^{\circ} 45^{\prime} \mathrm{N}$, long $110^{\circ} \mathrm{W}$, with elevations ranging from 1250 to about $1900 \mathrm{~m}$ above mean sea level. The WGEW surrounds the town of Tombstone, Arizona. Historically, the primary land uses on the WGEW have been cattle grazing and mining; recently, recreation and urbanization are increasing. Land ownership is divided among private, Arizona State Trust, and the US Department of the Interior, Bureau of Land Management. Portions of 5 ranches cover the area and grazing impacts were heavy at the turn of the century; however, stocking was generally light during the period of analysis.

The WGEW is located in the Basin and Range Province (Austin 1981). The headwaters are located in the Dragoon Mountains on the east side of the watershed and the generally westward-draining channel network is superimposed on coarse-grained Quaternary and Tertiary alluvium outwash on the northern half of the watershed and on Tertiary volcanics covering the southeastern portion of the watershed. The Tombstone Hills, with faulted and uplifted sedimentary rock underlain by late Tertiary volcanics, make up the southwestern and southern portions of the watershed (Gilluly 1956). The characteristics of the soils on the watershed are related to the underlying geology. Generally, the soils are well-drained, calcareous, gravelly to cobbly loams (Brekenfield et al. 1995). Shrubs, including creosote bush (Larrea tridentata [DC.] Cov.), acacia (Acacia constricta Benth.), and tarbush (Flourensia cernua DC.), dominate the lower two-thirds of the watershed.
The upper one-third supports gramma grasses (Bouteloua gracilis [Willd. ex Kunth] Lag. ex Griffiths and Bouteloua eriopoda [Torr.] Torr.), bush muhly (Mublenbergia porteri Scribn. ex Beal), and Lehmann lovegrass (Eragrostis lehmanniana Nees), with some invasion of the shrub species and curly mesquite (Hilaria belangeri [Steud.] Nash; Renard et al. 1993).

Average annual precipitation on the WGEW ranges from 303 $\mathrm{mm}$ at the lower end of the watershed to $339 \mathrm{~mm}$ near the upper end (Nichols et al. 2000). Precipitation during July, August, and September accounts for more than $60 \%$ of the annual total and is characterized by high-intensity, short-duration airmass thunderstorms. These storms generate most of the surface runoff in the normally dry channels (Osborn 1983). Precipitation on the WGEW exhibits a high degree of temporal and spatial variability both from season to season and from year to year.

Twenty-two stock ponds on the watershed collect surface runoff that can be used to water livestock, although alternate water sources generally are available. The ponds were constructed by excavating and building an earthen dam and spillway across drainage channels. Measured precipitation, runoff, and sediment data are available for 8 of the stock ponds (Fig. 1). These ponds were instrumented in the early 1960 s to evaluate the interactions and effects of various soil and vegetation complexes on local runoff, water yield, and sediment production. Stock pond capacity as measured in 2004 ranges from 3000 to $17900 \mathrm{~m}^{3}$ (Table 1). The watersheds above the 8 stock ponds range in size from 35.2 to 159.5 ha (Table 2). The area contributing to runoff into the 8 stock ponds is $4.8 \%$ ( $720 \mathrm{ha}$ ) of the WGEW area.

\section{Data Collection and Reduction}

Sediment accumulation was measured through periodic topographic surveys of the surface of each stock pond when the ponds were dry. Methods for measuring the volume of sediment in small reservoirs were established in 1935 by USDA Soil Conservation Service (SCS) personnel (Eakin 1936; Brakensiek et al. 1979). Although surveying equipment has evolved, the general procedures remain unchanged and are currently in use by the Natural Resources Conservation Service and other federal agencies (SCS 1983).

Topographic surveys of dry pond surfaces consist of measuring the location and elevation of a sufficient number of points within the pond to map the surface shape. Pond surfaces are surveyed up to spillway elevation or a point inclusive of the highest water level achieved during the period between surveys. During the 1950s and early 1960s, a plane table was used to conduct surveys at WGEW. A level and stadia rod replaced the plane table in the 1970s, and from 1993 to 2003, a Sokkia Set 3CII Total Station was used to measure pond surface topography. Historically, following plane table and stadia surveys, collected data were plotted by hand, and a planimeter was used to compute the area enclosed by a contour. Pond volumes were calculated by computing volumes between successive contours and summing over the range of elevations. The total pond capacity is taken to be the volume computed at the level of the spillway for each pond. As a pond fills with sediment, new surveys are required to update the pond capacity. Over time, pond capacity diminishes but is restored by periodic sediment removal. Surveys before and after cleanouts are used to account for the sediment removed. 


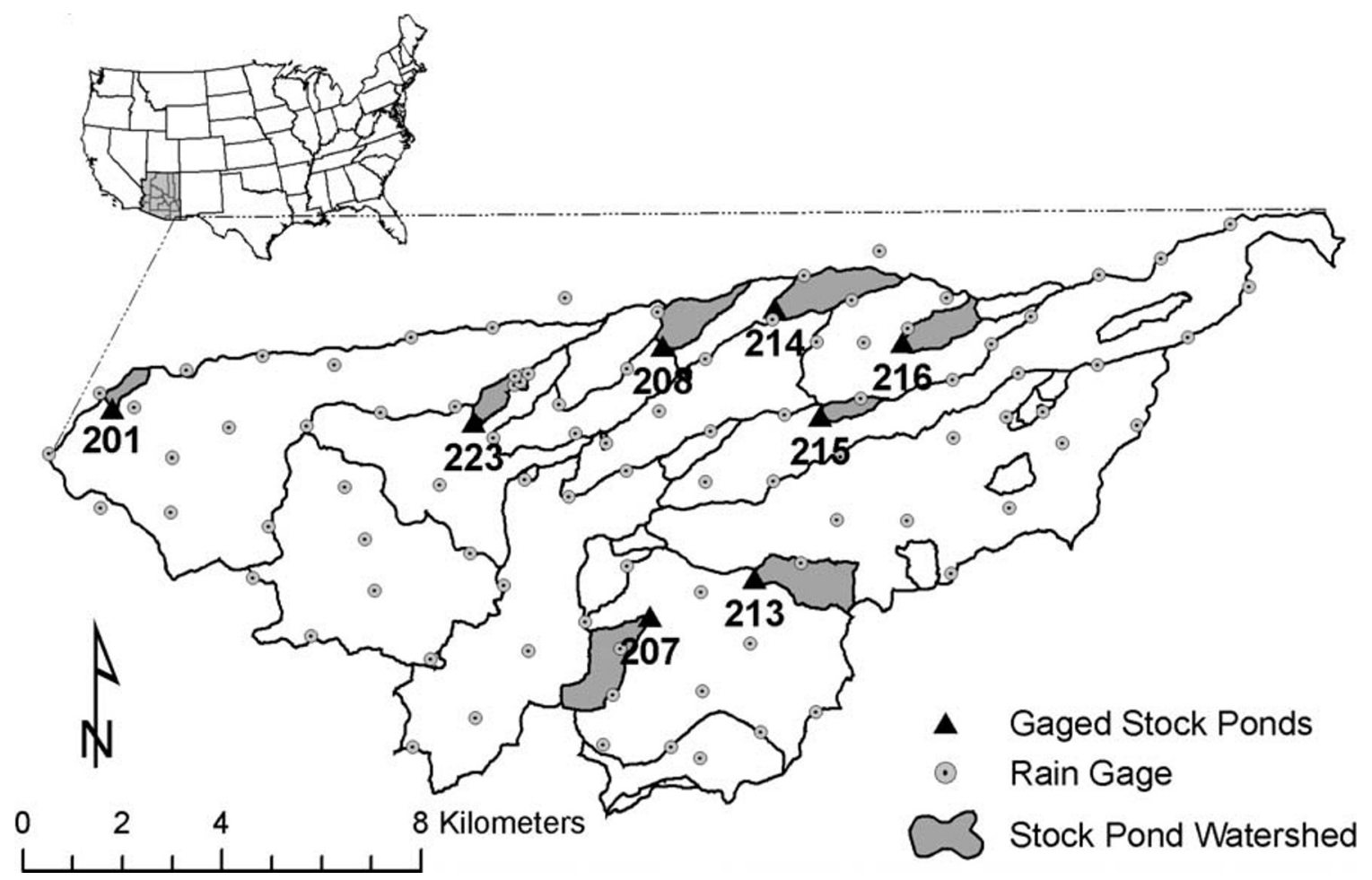

Figure 1. Walnut Gulch Experimental Watershed stock pond locations.

The data from each of the hand-plotted maps were converted to electronic format, and elevations were adjusted using vertical control benchmarks to establish common coordinate systems and datums for all maps illustrating each of the 8 ponds. Surfer (Surfer for Windows 1994) was used to regenerate contour plots, recompute volumes, and produce stage-volume curves. Thus, for each pond, a common datum, electronic data format, and computational method were used to compute pond volumes and quantify sediment accumulation.

Sediment yields are usually expressed in units of volume or mass per time, typically on an annual basis (Chow 1964). The measured differences in pond volume attributed to sediment influx were converted to sediment yields. Pond spills, although rare, occur frequently enough that sediment lost through spillway overflow was estimated and included in this analysis. Spill volumes were computed using standard weir formulae (Brakensiek et al. 1979). The sediment concentration in pond overflows has not been measured on the WGEW. In the absence of measured values, sediment samples from a depth-integrated sampler located within the WGEW were reviewed and a $1 \%$ sediment concentration was used to estimate sediment lost during pond overflow. The value of $1 \%$ may be high, given that sediment transported in overflows is expected to be made up of finer particles; however, scour in the spillway section may contribute sediment. Additional data collection and particle size analysis is necessary to refine this estimate. Sediment estimated in overflows was added to the accumulated pond sediment to determine the total sediment yield during each time period for each pond. The volumes of sediment accumulated were converted to mass values based on sediment bulk densities determined by sampling the surface of each stock pond. In 2004, a distributed grid of samples was collected and a mean bulk density value was determined for each pond. The overall average annual sediment yield from each of the watersheds was computed as the total volume of sediment divided by the number of years of record.

Each stock pond is instrumented to monitor water level. A vertical culvert pipe with slots at the bottom for water access acts as a stilling well. An instrument box on top of the stilling well pipe contains a water level recorder, which is connected to a pulley and a float that rests on the water surface. The relationship between water level and pond volume changes as sediment is deposited. Analog recorders (Brakensiek et al. 1979) on the ponds were converted to electronic potentiometer systems in 1999. Recorded water levels, in combination with the measured pond surface shape and spill volumes, were used

Table 1. Summary of sediment records, pond capacity, and overflow control for stock pond watersheds within the Walnut Gulch Experimental Watershed.

\begin{tabular}{|c|c|c|c|c|}
\hline $\begin{array}{l}\text { Stock } \\
\text { pond no. }\end{array}$ & $\begin{array}{l}\text { Period of } \\
\text { sediment } \\
\text { record }\end{array}$ & $\begin{array}{c}\text { Years of } \\
\text { record }\end{array}$ & $\begin{array}{c}\text { Pond } \\
\text { capacity } \\
\text { in } 2004 \\
\left(\mathrm{~m}^{3}\right)\end{array}$ & Overflow control \\
\hline 201 & 1967-2002 & 35 & 5300 & Earthen spillway \\
\hline 207 & 1962-2003 & 41 & 14800 & Earthen spillway \\
\hline 208 & 1973-2003 & 30 & 7600 & Sharp-crested weir \\
\hline 213 & $1962-2001$ & 39 & 4300 & Earthen spillway \\
\hline 214 & $1957-2003$ & 46 & 17900 & Earthen spillway \\
\hline 215 & 1966-2003 & 37 & 6600 & Sharp-crested weir \\
\hline 216 & 1962-2003 & 41 & 6600 & Sharp-crested weir \\
\hline 223 & 1956-2003 & 47 & 3000 & Sharp-crested weir \\
\hline
\end{tabular}


Table 2. GIS-derived characteristics of stock pond watersheds within the Walnut Gulch Experimental Watershed. ${ }^{1}$

\begin{tabular}{|c|c|c|c|c|c|c|c|c|}
\hline Characteristic & 201 & 207 & 208 & 213 & 214 & 215 & 216 & 223 \\
\hline Area (ha) & 44.0 & 110.8 & 92.2 & 159.5 & 150.5 & 35.2 & 84.2 & 43.8 \\
\hline \multicolumn{9}{|c|}{$\begin{array}{l}\text { Average } \\
\text { channel slope }\end{array}$} \\
\hline$(\mathrm{m} / \mathrm{m})$ & 0.0214 & 0.0549 & 0.0256 & 0.0169 & 0.0188 & 0.0220 & 0.0259 & 0.0253 \\
\hline \multicolumn{9}{|l|}{$\begin{array}{l}\text { Drainage } \\
\text { density }\end{array}$} \\
\hline$\left(\mathrm{km} \cdot \mathrm{km}^{-2}\right)$ & 7.20 & 4.09 & 9.63 & 1.25 & 7.08 & 6.13 & 10.29 & 13.29 \\
\hline \multicolumn{9}{|l|}{ Main channel } \\
\hline length (m) & 1018 & 2385 & 2218 & 1989 & 3504 & 1167 & 2218 & 1556 \\
\hline $\begin{array}{l}\text { Dominant } \\
\text { vegetation }\end{array}$ & $\begin{array}{l}\text { Whitethorn } \\
\text { acacia, } \\
\text { creosote bush, } \\
\text { tarbush }\end{array}$ & $\begin{array}{l}\text { Whitethorn } \\
\text { acacia, } \\
\text { creosote bush, } \\
\text { tarbush }\end{array}$ & $\begin{array}{l}\text { Black grama, } \\
\text { curly } \\
\text { mesquite }\end{array}$ & $\begin{array}{l}\text { Whitethorn acacia, } \\
\text { creosote bush, } \\
\text { tarbush, black grama, } \\
\text { curly mesquite }\end{array}$ & $\begin{array}{l}\text { Black grama, } \\
\text { curly } \\
\text { mesquite }\end{array}$ & $\begin{array}{l}\text { Whitethorn } \\
\text { acacia, } \\
\text { creosote bush, } \\
\text { tarbush }\end{array}$ & $\begin{array}{l}\text { Black grama, } \\
\text { curly } \\
\text { mesquite }\end{array}$ & $\begin{array}{l}\text { Whitethorn } \\
\text { acacia, } \\
\text { creosote bush, } \\
\text { tarbush }\end{array}$ \\
\hline $\begin{array}{l}\text { Dominant soil } \\
\text { texture }\end{array}$ & $\begin{array}{l}\text { Very gravelly } \\
\text { sandy loam }\end{array}$ & $\begin{array}{l}\text { Very gravelly } \\
\text { fine sandy } \\
\text { loam }\end{array}$ & $\begin{array}{l}\text { Gravelly fine } \\
\text { sandy loam }\end{array}$ & $\begin{array}{l}\text { Cobbly clay } \\
\text { loam/very } \\
\text { cobbly sandy } \\
\text { loam }\end{array}$ & $\begin{array}{l}\text { Very gravelly } \\
\text { loam/gravelly } \\
\text { fine sandy } \\
\text { loam }\end{array}$ & $\begin{array}{l}\text { Gravelly fine } \\
\text { sandy loam }\end{array}$ & $\begin{array}{l}\text { Very gravelly } \\
\text { loam }\end{array}$ & $\begin{array}{l}\text { Very gravelly } \\
\text { sandy loam }\end{array}$ \\
\hline Geology & Alluvium & $\begin{array}{l}\text { Alluvium/ } \\
\text { limestone }\end{array}$ & Alluvium & Alluvium/volcanics & Alluvium & Alluvium & Alluvium & Alluvium \\
\hline
\end{tabular}

${ }^{1}$ GIS indicates Geographic Information System.

to calculate event runoff volumes. Four of the ponds are instrumented with sharp-crested weirs located in the spillways (Table 1). Outflow at the remaining 4 ponds is through earthen spillways. In the absence of a spill, water depth was converted to volume based on the stage-volume relationship computed from topographic survey data. Unfortunately, the runoff records, although continuous when the recorders were operated, are not necessarily coincident with the time periods spanned by the sediment surveys. As a result, only a subset of the runoff records can be directly related to sediment yields. Watershed physiographic and geomorphic characteristics were quantified based on WGEW Geographic Information System (GIS) data layers and Environmental Systems Research Institute (ESRI) data analysis tools (Table 2). Computed values, such as average channel slope, main channel length, and drainage density, were based on data derived from digitized 1:5000 scale maps.

\section{RESULTS}

\section{Sediment Yield}

Sediment reaching the outlet of each pond watershed included 1) the amount of sediment accumulated in each pond, and 2) the amount of sediment that passed through each pond spillway during pond overflows. The total sediment yield from each watershed was determined by adding the sediment leaving through the spillway during overflows to the sediment accumulated in each pond.

Sediment yield volumes are summarized in Table 3 . The measured amount of sediment that accumulated during the period of record ranged from $360 \mathrm{~m}^{3}$ at Pond 213 to $11015 \mathrm{~m}^{3}$ at Pond 214. Overall, $7 \%$ of the runoff events into the ponds resulted in spills, but in years when spills occurred, the spill volume was $35 \%$ of the total runoff volume. Excluding Pond 213, the trap efficiency of studied ponds on the WGEW was

Table 3. Summary of sediment yield volumes and watershed denudation rates for stock pond watersheds within the Walnut Gulch Experimental Watershed.

\begin{tabular}{|c|c|c|c|c|c|c|}
\hline $\begin{array}{l}\text { Stock } \\
\text { pond no. }\end{array}$ & $\begin{array}{c}\text { Volume of } \\
\text { accumulated } \\
\text { sediment }\left(\mathrm{m}^{3}\right)\end{array}$ & $\begin{array}{l}\text { Volume of } \\
\text { accumulated } \\
\text { sediment }+ \text { sediment } \\
\text { through spillway }\left(\mathrm{m}^{3}\right)\end{array}$ & $\begin{array}{c}\text { Sediment } \\
\text { yield }\left(\mathrm{m}^{3} \cdot \mathrm{y}^{-1}\right)\end{array}$ & $\begin{array}{l}\text { Unit sediment yield } \\
\qquad\left(\mathrm{m}^{3} \cdot \mathrm{ha}^{-1} \cdot \mathrm{y}^{-1}\right)\end{array}$ & $\begin{array}{l}\text { Denudation rate } \\
\left(\mathrm{mm} \cdot \mathrm{ha}^{-1} \cdot \mathrm{y}^{-1}\right)\end{array}$ & $\begin{array}{c}\text { Total denudation } \\
\left(\mathrm{mm} \cdot \text { period of record }^{-1}\right)\end{array}$ \\
\hline 201 & 870 & 962 & 27 & 0.6 & 0.062 & 2.2 \\
\hline 207 & 1970 & 2353 & 57 & 0.5 & 0.052 & 2.1 \\
\hline 208 & 1090 & 1433 & 48 & 0.5 & 0.052 & 1.6 \\
\hline 213 & 360 & 2899 & 74 & 0.5 & 0.047 & 1.8 \\
\hline 214 & 11015 & 11946 & 260 & 1.7 & 0.173 & 7.9 \\
\hline 215 & 2970 & 3164 & 86 & 2.4 & 0.243 & 9.0 \\
\hline 216 & 5830 & 6480 & 158 & 1.9 & 0.188 & 7.7 \\
\hline 223 & 5560 & 6125 & 130 & 3.0 & 0.298 & 14.0 \\
\hline
\end{tabular}


Table 4. Summary of sediment yield mass and pond trap efficiencies for stock pond watersheds within the Walnut Gulch Experimental Watershed.

\begin{tabular}{lcccccc}
\hline \multicolumn{5}{c}{ Average } \\
Stock \\
$\begin{array}{c}\text { Average } \\
\text { pulk } \\
\text { density } \\
\text { no. }\end{array}$ & $\begin{array}{c}\text { Average } \\
\text { mass } \\
\left(\mathrm{g} \cdot \mathrm{cm}^{-3}\right)\end{array}$ & $\begin{array}{c}\text { accumulated } \\
\text { through } \\
\left(\mathrm{t} \cdot \mathrm{y}^{-1}\right)\end{array}$ & $\begin{array}{c}\text { Average } \\
\text { spillway } \\
\left(\mathrm{t} \cdot \mathrm{y}^{-1}\right)\end{array}$ & $\begin{array}{c}\text { Average } \\
\text { mass } \\
\left(\mathrm{t} \cdot \mathrm{y}^{-1}\right)\end{array}$ & $\begin{array}{c}\text { total } \\
\text { mass } \\
\left(\mathrm{t} \cdot \mathrm{ha}^{-1} \cdot \mathrm{y}^{-1}\right)\end{array}$ & $\begin{array}{c}\text { Trap } \\
\text { efficiency } \\
(\%)\end{array}$ \\
\hline 201 & 1.37 & 34 & 4 & 38 & 0.9 & 90.5 \\
207 & 1.11 & 53 & 10 & 63 & 0.6 & 83.7 \\
208 & 1.18 & 43 & 13 & 56 & 0.6 & 76.1 \\
213 & 1.20 & 11 & 78 & 89 & 0.6 & 12.4 \\
214 & 1.19 & 285 & 24 & 309 & 2.1 & 92.2 \\
215 & 1.29 & 104 & 7 & 111 & 3.1 & 93.9 \\
216 & 1.21 & 172 & 19 & 191 & 2.3 & 90.0 \\
223 & 1.23 & 146 & 15 & 161 & 3.7 & 90.8 \\
\hline
\end{tabular}

relatively high, ranging from $76 \%$ to $94 \%$, and during individual years was often $100 \%$ (Table 4). A notable exception was Pond 213, where the trap efficiency was only $12 \%$. Although runoff and sediment yield are expected to be relatively low from this watershed because of the grass cover, cohesive soils, and a poorly developed channel network, Pond 213 is undersized relative to the contributing watershed area and its capacity was often exceeded. Because a significant portion of sediment is lost through overflows, the amount of sediment accumulated in Pond 213 is not indicative of the actual watershed sediment yield. After correcting for sediment in overflows, the total sediment yields from the 8 watersheds ranged from $962 \mathrm{~m}^{3}$ at Pond 201 to $11946 \mathrm{~m}^{3}$ at Pond 214.

Sediment yields computed on a per-hectare basis provide a means for comparing watersheds. The annual average sediment yield from the 8 WGEW stock pond watersheds ranged from 0.5 to $3.0 \mathrm{~m}^{3} \cdot \mathrm{ha}^{-1} \cdot \mathrm{y}^{-1}$ (Table 3 ), or 0.6 to 3.7 $\mathrm{t} \cdot \mathrm{ha}^{-1} \cdot \mathrm{y}^{-1}$. When converted to denudation rates over the watersheds, this corresponds to a minimum of $1.8 \mathrm{~mm}$ of soil loss over the 159-ha Pond 213 watershed during the 35-year record, and a maximum of $14.0 \mathrm{~mm}$ over the 43.8 -ha Pond 223 watershed during the 46-year record. It is not likely that the only source of the sediment delivered to the watershed outlets was eroding uplands, but there are insufficient data to quantify sources fully.

Factors Contributing to Sediment Yield. Sediment yield measurements are an integrated measure of erosion, transport, and deposition processes, and are often interpreted over long time periods. Runoff is the primary factor in predicting sediment yield (Toy et al. 2002). Average annual runoff into the ponds ranged from a high of $24.8 \mathrm{~mm}(\mathrm{SD}=24.6 \mathrm{~mm})$ to a low of $7.6 \mathrm{~mm}(\mathrm{SD}=9.8 \mathrm{~mm}$; Table 5$)$. Overall, $88 \%$ of the runoff events at the stock ponds occurred between 15 June and 15 September during the "monsoon" season. The remaining $12 \%$ occurred during nonmonsoon months.

The relationship between runoff and sediment yield was evaluated for 3 cases: 1) overall total runoff volume vs. total sediment yield among the 8 watersheds $(n=8) ; 2)$ total runoff volume vs. total sediment yield for each measurement period within the overall period of record among all of the ponds
Table 5. Summary of runoff records and runoff characteristics for stock pond watersheds within the Walnut Gulch Experimental Watershed.

\begin{tabular}{|c|c|c|c|c|c|c|}
\hline \multirow{2}{*}{$\begin{array}{l}\text { Stock } \\
\text { pond } \\
\text { no. }\end{array}$} & \multirow{2}{*}{$\begin{array}{l}\text { Drainage } \\
\text { area (ha) }\end{array}$} & \multirow[b]{2}{*}{ Period of record } & \multirow[b]{2}{*}{$\begin{array}{l}\text { Years of } \\
\text { record }\end{array}$} & \multicolumn{2}{|c|}{ Annual runoff } & \multirow[b]{2}{*}{$\begin{array}{c}\text { Rainfall/runoff } \\
\text { ratio }^{1}\end{array}$} \\
\hline & & & & $\begin{array}{l}\text { Mean } \\
(\mathrm{mm})\end{array}$ & $\begin{array}{c}\mathrm{SD} \\
(\mathrm{mm})\end{array}$ & \\
\hline 201 & 44 & $1966-2003$ & 38 & 11.03 & 10.44 & 11.9 \\
\hline 207 & 110.8 & 1962-1986; 1996-2003 & 33 & 7.64 & 9.78 & 12.1 \\
\hline 208 & 92.2 & 1973-1986; 1996-2003 & 22 & 13.43 & 14.66 & 8.5 \\
\hline 213 & 159.5 & 1969-1986; 1996-2003 & 26 & 9.51 & 16.14 & 12.5 \\
\hline 214 & 150.5 & 1960-2003 & 44 & 16.80 & 15.67 & 7.6 \\
\hline 215 & 35.2 & 1966-1986; 1996-2003 & 29 & 24.84 & 24.58 & 5.5 \\
\hline 216 & 84.2 & 1966-2003 & 38 & 11.96 & 10.73 & 10.4 \\
\hline 223 & 43.8 & 1960-1977; 1985-2003 & 37 & 15.43 & 16.24 & 7.6 \\
\hline
\end{tabular}

${ }^{1}$ Ratio for runoff-producing storms.

$(n=81)$; and 3$)$ runoff versus sediment yield for measurement periods within each of the 8 ponds ( $n$ ranges from 8 to 15 ).

To determine the relationship between overall long-term sediment yield and overall runoff volume, simple linear regression was performed to determine the relationship between total runoff volume $(Q$, in cubic meters) and total sediment yield ( $S Y$, in cubic meters) based on combined data from all pond watersheds:

$$
S Y=0.01 Q+361\left(R^{2}=0.75 ; P=0.005\right)
$$

This indicates that for long time periods, $75 \%$ of the variability in total long-term sediment yield on small watersheds within the WGEW is accounted for by variability in total runoff volume. Because a significant proportion of runoff, and thus computed sediment, is lost during pond overflows at Ponds 213 and 208, there is a high correlation between sediment yield and runoff volume. Although excluding these two ponds from the analysis did not significantly alter the relationship between overall runoff volume and sediment yield, measurements of sediment concentrations in overflows would improve estimates of sediment lost during flow through the spillways.

The WGEW dataset contains sufficient data to analyze the relationship between sediment yield and runoff for time periods within the long-term record. Sediment yield and runoff volume were computed for each time period between sediment surveys for each of the 8 ponds $(n=81)$. Linear regression was performed to examine further the relationship between runoff volume and sediment yield:

$$
S Y=0.0076 Q+102.28\left(R^{2}=0.31 ; P<0.001\right)
$$

This weaker statistical relationship between runoff and sediment yield for time periods within the longer term record indicates that long-term sediment yield rates hide short-term variability caused by factors other than runoff volume.

Each of the 8 watersheds is distinguished by characteristics that affect runoff and thus sediment yield. For each pond, runoff volume during each period between sediment surveys was related to sediment yield. Time periods between surveys ranged from 1 to 12 years. Five of the ponds (207, 208, 213, 215, and 216) exhibited a significant linear relationship between runoff and sediment yield $(P=0.05)$, whereas the 
Table 6. Summary of regression relationships between sediment yield and runoff determined for stock pond watersheds within the Walnut Gulch Experimental Watershed.

\begin{tabular}{llll}
\hline $\begin{array}{l}\text { Stock } \\
\text { pond no. }\end{array}$ & Regression equation & $R^{2}$ & $P$ value \\
\hline 201 & $\mathrm{SY}^{1}=0.003 \mathrm{Q}+39$ & 0.26 & 0.09 \\
207 & $\mathrm{SY}=0.008 \mathrm{Q}+2.8$ & 0.63 & 0.01 \\
208 & $\mathrm{SY}=0.005 \mathrm{Q}+10.7$ & 0.86 & 0.0003 \\
213 & $\mathrm{SY}=0.008 \mathrm{Q}-64.7$ & 0.99 & 0.00 \\
214 & $\mathrm{SY}=0.006 \mathrm{Q}+352$ & 0.15 & 0.16 \\
215 & $\mathrm{SY}=0.006 \mathrm{Q}+172$ & 0.61 & 0.02 \\
216 & $\mathrm{SY}=0.01 \mathrm{Q}-104$ & 0.63 & 0.02 \\
223 & $\mathrm{SY}=0.02 \mathrm{Q}+112$ & 0.35 & 0.06 \\
\hline
\end{tabular}

${ }^{1} S Y$ indicates sediment yield; $Q$, runoff.

remaining ponds (201, 214, and 223) did not have such statistically significant relationships. For the 5 ponds exhibiting significant linear relationships, the coefficient of the runoff term in the resulting regression equations ranged from 0.005 to 0.01 (Table 6). As noted previously, the strong relationship between sediment yield and runoff at Pond 213 is caused by the portion of sediment that is transported during spills.

As noted by Dendy (1968), sediment yields from small reservoirs exhibit great variability because the contrast in the factors affecting sediment yield is greater among small watersheds than it is among large watersheds. Factors other than runoff affect sediment yield, and within the WGEW, individual watersheds exhibit considerable variability in physiographic and geomorphic features (Table 2). To assess which characteristics affect sediment yield among the WGEW watersheds, GISderived values, including watershed area, drainage network characteristics, soils, and vegetation were compared with watershed sediment yields.

Simple linear regressions were performed between physiographic and geomorphic factors and sediment yield for each individual watershed. No significant relationships were found between sediment yield and watershed area, average channel slope, or drainage density. However, a significant relationship was found between the ratio of watershed area to main channel length and sediment yield $\left(R^{2}=0.46 ; P=0.06\right)$. Because channels control runoff into the ponds, they play a direct role in sediment supply, transport, and storage. More detailed measurements to characterize the watershed channel networks are needed to relate internal watershed sediment transport and deposition processes to sediment delivery at the watershed outlets.

General spatially distributed watershed characteristics describing dominant vegetation, soil texture, and underlying geology derived from GIS data were used to divide the study watersheds into different treatment groups. Only dominant vegetation produced a partitioning with sufficient observations within each treatment group to conduct statistical analyses. Although it is known that vegetative cover plays a critical role in reducing soil erosion (Wischmeier and Smith 1978), and that differences in average annual sediment yields between grassand brush-dominated rangeland watersheds have been reported (Osborn et al. 1978), the data used in this study were insufficient to test the relationship further. An $f$ test for the difference in

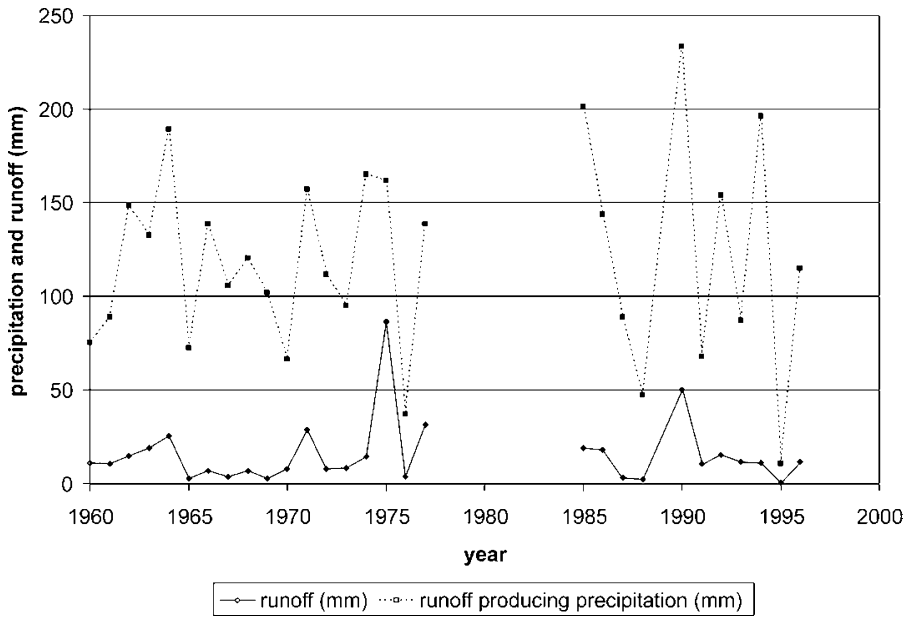

Figure 2. Annual runoff producing precipitation and associated runoff at Pond 223. There is a break in the record when the recorder was not operating.

treatment means between grass- and brush-dominated watersheds was conducted as the first step in a standard analysis of variance. This resulted in an $f$ statistic of 0.4 , which is far less than the critical value of $5.98(P=0.05)$, thus the treatment means are not statistically different. Therefore, further statistical analysis was not supported.

Although data were not sufficient to quantify statistically the relationship between dominant soil texture and sediment yield, some observations can be made. The lowest sediment yield was generated from the watershed associated with Pond 213, located in an area with heavy clay soils. The highest sediment yields were generated from the watershed associated with Pond 223, within which eroding uplands supply sediment and an incised channel network facilitates sediment delivery to the pond.

Temporal Variability in Sediment Yield. Long-term average annual sediment yield values hide both inter- and intra-annual variability of this factor within a given watershed. In many upland channels in semiarid regions, sediment is moved sporadically by intermittent runoff events (Reid et al. 1998). In fact, the average annual runoff duration for flows recorded at Pond 223 during the 37 years of record was $10.0 \mathrm{~h} \cdot \mathrm{y}^{-1}(\mathrm{SD}=12.5)$. These ephemeral flows often redeposit sediment within the drainage network, which complicates efforts to relate soil erosion and sediment yield (Osterkamp and Toy 1997). Eroded soil may remain in storage within a watershed for long time periods.

Average annual sediment yield values between surveys were computed to assess temporal variability in stock pond sediment yield. For each pond, the particular time period over which computations are performed and the length of the time period influence the resulting computed sediment yield. For example, at Pond 223, although the 47-year average annual sediment yield rate is $3.0 \mathrm{~m}^{3} \cdot \mathrm{ha}^{-1} \cdot \mathrm{y}^{-1}$, sediment yield ranged from a low of $1.2 \mathrm{~m}^{3} \cdot \mathrm{ha}^{-1} \cdot \mathrm{y}^{-1}$ from 1965 to 1975 and a high of $5.32 \mathrm{~m}^{3} \cdot \mathrm{ha}^{-1} \cdot \mathrm{y}^{-1}$ from 2002 to 2003 . The $1965-1975$ period included 4 years of below-average runoff, whereas runoff from 2002 to 2003 was above average (Fig. 2). When the measurement period covers more than one year, the annual variability in sediment yield is smoothed. The temporal variability in 
sediment yields adds to the complexity of generalizing sediment yield rates across rangeland regions.

\section{DISCUSSION AND MANAGEMENT IMPLICATIONS}

Stock ponds are ubiquitous across rangelands and they can provide valuable information on sediment yield rates from small watersheds. Average annual sediment yield values provide a temporally integrated measure of soil erosion and sediment transport processes, and are a useful index for comparing among watersheds over long time periods. Common management practices for erosion control on rangelands typically are applied at the hillslope and subwatershed scale, and in reducing erosion they may affect sediment yield. Several factors add to the complexity in interpreting this information, including 1) spatial variability in watershed characteristics, 2) temporal variability in rainfall and runoff, and 3) the relationships among soil erosion, sediment transport, deposition, and yield processes.

Given the range in sediment yields among proximate watersheds in the $150 \mathrm{~km}^{2}$ WGEW, caution should be exercised in extending the results of local measurements and interpretations. Runoff volume was shown to be a dominant factor in determining sediment yield, but runoff volume alone is not sufficient to explain the variability in sediment yield among these small watersheds. Clearly, there are differences in sediment yields among the watersheds, and determining the sources of these differences will require additional measurements to improve the resolution of data currently available. Until highresolution data are available and additional statistical analyses are conducted, developing generalized sediment yield relationships may remain intractable, making land management difficult and adding complexity to developing prediction models.

Long-term sediment yield rates are related to runoff. However, interpretations of sediment yields need to be made in the context of local climate variability, with careful attention to rainfall and runoff patterns during the period of record. In thunderstorm-dominated semiarid regions, the variability of sediment yield within an individual watershed in response to highly variable precipitation and runoff will be masked by temporally integrated long-term measurements. In contrast, measurement over short time periods may introduce significant bias into yield estimates if the measurement period happens to coincide with a period of drought or above-average rainfall. As a result, average annual sediment yield rates may not provide sufficient information to interpret causes and effects of upland management over short time periods.

Finally, sediment yield values are an integrated measure of erosion, transport, and deposition processes. As such, they are not directly comparable to erosion rates. Although denudation rates were presented for comparison, computed sediment yields provide no information on sediment sources, internal watershed deposition, sediment storage time, or the processes that move sediment within the watershed. The processes that control erosion and sediment yield vary with scale. Hillslope erosion is controlled by factors such as slope and ground cover and is generally assessed for areas less than 10 ha, whereas sediment yield is usually assessed from watersheds based on measurement at the watershed outlet (Lane et al. 1997). At the watershed scale, sediment deposition and storage, both within the channel network and along toeslopes and floodplains, can account for a considerable amount of eroded material (Osterkamp and Toy 1995). In addition, the efficiency with which the channel network conveys sediment through the watershed is a primary control on downstream delivery (Laronne and Reid 1993; Tooth 2000). These components of the sediment yield processes need to be quantified to determine the relationship between upland erosion and downstream sediment yield. Identifying the areas within a watershed where sediment production is the highest is a step toward focusing remediation efforts to reduce erosion.

\section{CONCLUSION}

This study summarizes sediment yields from subwatersheds within the WGEW since 1956 for periods of record ranging from 30 to 47 years. Sediment yields were variable in time and in space and ranged from 0.5 to $3.0 \mathrm{~m}^{3} \cdot \mathrm{ha}^{-1} \cdot \mathrm{y}^{-1}$, with a mean of $1.4 \mathrm{~m}^{3} \cdot \mathrm{ha}^{-1} \cdot \mathrm{y}^{-1}$ and a standard deviation of $1.0 \mathrm{~m}^{3} \cdot \mathrm{ha}^{-1} \cdot \mathrm{y}^{-1}$. Although the reported sediment yield rates are not high with respect to those from cultivated agricultural regions, many rangeland soils are relatively shallow and denudation of the surface soil is a critical loss.

As expected, runoff volume was a significant factor $(P=0.005)$ in explaining the variability in sediment yield. In addition, the ratio of watershed area to main channel length significantly described $(P=0.06)$ sediment yield, suggesting that more detailed measurements are needed to characterize the watershed channel networks to relate internal watershed sediment transport and deposition processes to sediment delivery at the watershed outlets. This need is emphasized by the present observation of considerable variability $(\mathrm{CV}=71 \%)$ in sediment yields from proximate watersheds. To reach the goal of generalizing sediment yield rates across rangeland regions to help better implement management practices, additional research is necessary to determine the relative influence of rainfall and runoff patterns, and watershed physiographic and geomorphic characteristics on semiarid rangeland sediment transport.

\section{ACKNOWLEDGMENTS}

This study was based on a field project initiated in 1953 and continued through the efforts of many people, including Ken Renard, Don Chery, Herb Osborn, Roger Simanton, Howard Larson, Jeff Stone, and Leonard Lane. Their work and the help of John Smith, Bill Flack, Kathleen Carey, and Catlow Shipek are gratefully acknowledged.

\section{LITERATURE CITED}

Austin, M. E. 1981. Land resource regions and major land resource areas of the United States. Washington, DC: USDA. Agricultural Handbook 296. 190 p.

Brakensiek, D. L., H. B. Osborn, AND W. J. RaWLS [COORDINATORS]. 1979. Field manual for research in agricultural hydrology. Washington, DC: USDA. Handbook 224. $550 \mathrm{p}$.

Breckenfield, D. J., W. A. Svetlik, and C. E. McGuire. 1995. Soil survey of Walnut Gulch Experimental Watershed. Tucson, AZ: USDA Soil Conservation Service. CHow, V. T. [ED.]. 1964. Handbook of applied hydrology. New York, NY: McGraw Hill. Dendy, F. E. 1968. Sedimentation in the nation's reservoirs. Journal of Soil and Water Conservation 23:135-137. 
Dendy, F. E., and G. C. Bolton. 1976. Sediment yield-runoff drainage area relationships in the United States. Journal of Soil and Water Conservation 31:264-266.

EAKIN, H. M. 1936. Silting of reservoirs. (Revised by C. B. Brown in 1939) Washington, DC: USDA. Agricultural Technical Bulletin 524. 168 p.

GILLULY, J. 1956. General geology of central Cochise County, Arizona. Washington, DC: USGS. Professional Paper 281. $169 \mathrm{p}$.

Lane, L. J., M. Hernandez, and M. H. Nichols. 1997. Processes controlling sediment yield from watersheds as functions of spatial scale. Environmental Modeling and Software 12:355-369.

LaRRone, J. B., AND I. ReID. 1993. Very high rates of bedload sediment transport by ephemeral desert rivers. Nature 366:148-150.

National Research Councll. 1998. New strategies for America's Watersheds. Washington, DC: National Academy Press. $311 \mathrm{p}$.

Nichols, M. H., K. G. Renard, and H. B. Osborn. 2000. Precipitation changes from 1956-1996 on the Walnut Gulch Experimental Watershed. Journal of the American Water Resources Association 38:161-172.

OsBoRn, H. B. 1983. Precipitation characteristics affecting hydrologic response in southwestern rangelands. Washington, DC: USDA. Agricultural Research Service Agricultural Reviews and Manuals ARM-W-34. 55 p.

Osborn, H. B., J. R. Simanton, and K. G. Renard. 1978. Sediment yields of rangeland watersheds. Proceedings of the First International Rangeland Congress; 14-18 August 1978; Denver, CO. Denver, CO: Society for Range Management. p 329-330.

Osterkamp, W. R., AND T. J. Toy. 1997. Geomorphic considerations for erosion prediction. Environmental Geology 29:152-157.

Perciasepe, R. 1997. New policies for establishing and implementing total maximum daily loads (TMDLs). Available at: http://www.epa.gov/OWOW/ tmdl/ratepace.html. Accessed 30 March 2005.

Pimentel, D., C. Harvey, P. Resosudarmo, K. Sinclair, D. Kurz, M. McNair, S. Crist, L. Shpritz, L. Fitton, R. Saffouri, and R. Blair. 1995. Environmental and economic costs of soil erosion and conservation benefits. Science 267: 1117-1122.

Reid, I., D. M. Powell, and J. B. Laronne. 1998. Flood flows, sediment fluxes and reservoir sedimentation in upland desert rivers. In: $\mathrm{H}$. Wheater and C. Kirkby [EDS.]. Hydrology in a changing environment. New York, NY: John Wiley \& Sons. p 378-386.

Renard, K. G, L. J. Lane, J. R. Simanton, W. E. Emmerich, J. J. Stone, M. A. Weltz, D. C. GoodRich, AND D. S. Yakowitz. 1993. Agricultural impacts in an arid environment: Walnut Gulch studies. Hydrological Science and Technology 9:145-190.

Renard, K. G., And J. J. Stone. 1982. Sediment yield from small semiarid rangeland watersheds. In: Proceedings of the workshop on estimating erosion and sediment yield on rangelands; 7-9 March 1981; Tucson, AZ. Washington, DC: USDA. ARS Agricultural Reviews and Manuals ARM-W-26. June 1982. p 129144.

Soll Conservation Service. 1983. Field investigations and surveys. In: National engineering handbook NEH-3. Washington, DC: USDA SCS.

SURFER FOR Windows [computer program]. 1994. Golden, CO: Golden Software, Inc. Тоотн, S. 2000. Process, form and change in dryland rivers: a review of recent research. Earth-Science Reviews 51:67-107.

Toy, T. J., G. R. Foster, And K. G. Renard. 2002. Soil erosion: Processes, prediction, measurement, and control. New York, NY: John Wiley \& Sons. 338 p.

[UNeP] United Nations Environmental Programme. 1997. World atlas of desertification. London: Edward Arnold. 182 p.

USDA. 1973. Summary of reservoir sediment deposition surveys made in the United States through 1970. Miscellaneous Publication 1226. Washington, DC: Sedimentation Committee, Water Resources Council. 80 p.

WischmeleR, W. H., AND D. D. Smith. 1978. Predicting rainfall erosion losses: guide to conservation planning. USDA, Agricultural Handbook 537. Washington, DC: US Government Printing Office. 58 p. 